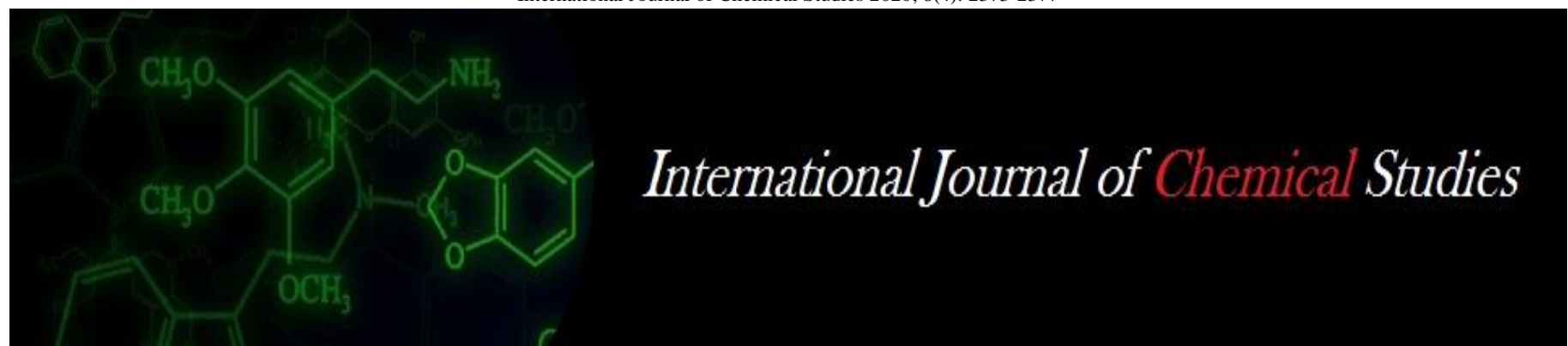

P-ISSN: 2349-8528

E-ISSN: 2321-4902

www.chemijournal.com

IJCS 2020; 8(4): 2373-2377

(C) 2020 IJCS

Received: 16-05-2020

Accepted: 20-06-2020

Potala Harshita Mala

Department of Sericulture,

College of Agriculture

University of Agricultural

Sciences GKVK, Bengaluru,

Karnataka, India

Chandrashekhar S

Department of Sericulture,

College of Agriculture

University of Agricultural

Sciences GKVK, Bengaluru,

Karnataka, India

Corresponding Author:

Potala Harshita Mala

Department of Sericulture,

College of Agriculture

University of Agricultural

Sciences GKVK, Bengaluru,

Karnataka, India

\section{Influence of Seri-waste bio-digester on biochemical constituents, growth and yield of mulberry}

\author{
Potala Harshita Mala and Chandrashekhar S
}

DOI: https://doi.org/10.22271/chemi.2020.v8.i4aa.9988

\begin{abstract}
A field experiment was conducted to study the influence of seri waste biodigester on growth and yield parameters of $\mathrm{V}_{1}$ mulberry at department of sericulture during 2017-18. The results indicated that, application of $50 \%$ Seri Bio-digester effluent $+25 \%$ Biodigester effluent $+25 \%$ RDF $\left(\mathrm{T}_{4}\right)$ increased the mulberry yield attributing parameters viz., plant height $(163.19 \mathrm{~cm})$, number of branches per plant (13.32), number of leaves per branch (33.00), leaf area $\left(208.33 \mathrm{dM}^{2}\right)$ and leaf yield (1012.33 g/plant) per plant compared to control. Significant increase in leaf moisture, total chlorophyll, crude protein and crude fibre was observed in T4 treatment compared to all other treatments. Application of 50\% Seri Biodigester effluent $+25 \%$ Biodigester effluent $+25 \%$ RDF significantly increased both biochemical constituents and yield parameters of mulberry leaves.
\end{abstract}

Keywords: Mulberry, Seri waste bio digester, biochemical constituents, yield parameters

\section{Introduction}

Sericulture is an agro-based industry which is mainly practiced by small and marginal farmers in India for regular source of income and it generates enormous quantity of bio-waste. In this regard the use of Seri-waste in the biogas production has come up recently, the use of Biodigester effluent on the growth of mulberry may add the nutrition to the soil and improves the fertility levels may in turn contribute to the higher growth and yield of mulberry.

Karnataka as a sericulturally leading state producing enormous quantity of biomass which provides an alternative source of energy as the biogas generated by bio-digester and also it is good organic sources of nutrient to the soil. Realization of the fertility level of the soil nutrients is the most important factor in sericulture to obtain good cocoon harvest and inturn resulting in good quality silk. However, microbial conversion of organic matter to methane has become attractive as a method of waste treatment and resource recovery. Bio-digesters are however, good solutions for rural agrarian communities, intensive livestock farms, towns and cities where large volumes of domestic and animal wastes can produce significant quantities of methane. Indiscriminate use of chemical fertilizers and pesticides leads to the increased soil fertility depletion. One of the ways to solve the problem is the promotion of integrated farming systems, with minimal external inputs and recycling of all wastes. (Preston and Leng, 1989) ${ }^{[8]}$. The most important feature of this approach is the recycling of animal and plant wastes in order to prevent deterioration of soil fertility through loss of nutrients and organic matter, erosion and salinity. (Rodriguez and Preston 1996) ${ }^{[11]}$. Hence, application of manures to the soil can reduce environmental pollution and also improve the soil fertility through recycling of plant nutrients.

\section{Materials and Methods}

A field Experiment was conducted during Kharif season from August - February, 2017-18 at the Department of Sericulture, University of Agricultural Sciences, Gandhi Krishi Vigyan Kendra, Bengaluru. The type of soil is clay loam.

\section{Treatment Details}

$\mathbf{T}_{\mathbf{1}}: 100 \%$ Recommended Dose of Fertilizers 
$\mathbf{T}_{\mathbf{2}}: \mathbf{7 5 \%}$ Seri Bio-digester effluent+ 25\% RDF

$\mathbf{T}_{3}$ : $50 \%$ Seri Bio-digester effluent $+25 \%$ Compost $+25 \%$ $\mathrm{RDF}$

T4: 50\% Seri Bio-digester effluent+25\% Bio-digester effluent $+25 \% \mathrm{RDF}$

T5: 25\% Seri Bio-digestereffluent $+25 \%$ Bio-digestereffluent $+25 \%$ Vermicompost +

$25 \%$ Compost

T6: $75 \%$ Seri Bio-digester effluent $+25 \%$ Vermicompost

$\mathbf{T}_{7-5}$ 50\%Compost+50\% Seri bio-digester effluent

T8- 100\% Vermicompost

T9- 100\% Bio-digester effluent

$\mathbf{T}_{\mathbf{1 0}}$-100\%Compost

$\mathbf{T}_{11-100 \%}$ Seri Bio-digester effluent

\section{Leaf analysis}

Mulberry leaf samples were collected from every treatment at 60 days after pruning for analysis.

\section{Total nitrogen}

Nitrogen content of leaves was estimated by adopting Micro Kjeldhal digestion distillation method.

\section{Digestion of plant samples with di-acid mixture}

A powdered sample of $0.5 \mathrm{~g}$ was pre-digested with $5 \mathrm{ml}$ of concentrated HNO3 and again digested with a di-acid mixture (HNO3: $\mathrm{HClO} 4$ in the proportion of 10:4 ratio). Volume of the digest was made up to $100 \mathrm{ml}$ with distilled water and preserved for total elemental analysis (Jackson, 1967) ${ }^{[4]}$.

\section{Total phosphorus}

The total phosphorus content was determined by taking a known volume of the digested materials by adopting the Vanadomolybdophosphoric yellow colour method as described by Jackson (1967) ${ }^{[4]}$.

\section{Total potassium}

Using the respective di-acid, the total potassium content of the above samples was estimated by atomizing the diluted digest to a calibrated flame photometer under suitable measuring conditions as described by Jackson (1967) ${ }^{[4]}$.

\section{Secondary nutrients}

Calcium and magnesium were determined by the EDTA titration or Versonate-titraton method. Sulphur content in the di acid digested sample was estimated by turbidometric method as outlined by Jackson (1967) ${ }^{[4]}$.

\section{Micronutrients}

The content of $\mathrm{Zn}, \mathrm{Mn}, \mathrm{Cu}$ and $\mathrm{Fe}$ in the residues was determined by using atomic absorption spectrophotometer with appropriate hallow cathode lamps (Lindsey and Norwell, 1978) ${ }^{[5]}$.

\section{Estimation of biochemical constituents of V1 mulberry}

The collected mulberry leaf samples at the time of harvest were dried at $60^{\circ} \mathrm{C}$ in hot air oven, powdered using a grinder fitted with stainless steel blades and preserved in polythene bags for further analysis (Jackson, 1967) ${ }^{[4]}$. The leaf moisture content, protein and fibre contents were carried out using standard reference of AOAC (1990) protocol.

\section{Leaf moisture}

Moisture content of mulberry leaf expressed in\% wet basis, was carried out by hot air oven method at $105 \pm 1{ }^{\circ} \mathrm{c}$ for 24 hours and continue the same procedure till constant results was obtained and then percent moisture content was determined by following formula

$$
\text { Moisture content }(\% \text { w. b })=\frac{\left(\begin{array}{c}
\text { Initial weight } \\
\text { of leaf }
\end{array}\right)-\left(\begin{array}{c}
\text { Final weight } \\
\text { of leaf }
\end{array}\right)}{\text { Initial weight leaf }} \times 100
$$

\section{Chlorophyll estimation}

Chlorophyll content in mulberry leaf was determined by the following procedure described by Hiscox and Isrealstam (1979) ${ }^{[3]}$. The total chlorophyll content of leaf was computed using the formula suggested by Arnon (1949) ${ }^{[2]}$.

\section{Total Chlorophyll}

$\mathrm{Mg} / \mathrm{g}$ fresh weight $=\frac{20.2(\text { O.D. } 645)-8.02(\text { O.D. } 663) \times \text { Volume }}{1000 \mathrm{~g} \text { weight of leaves }(\mathrm{g})}$

\section{Protein}

The nitrogen value, which is the precursor for protein of a substance, was determined by micro Kjeldahl method involving digestions, distillation and titration of the sample. The nitrogen in protein or any other organic material is converted to ammonium sulphate by $\mathrm{H}_{2} \mathrm{SO}_{4}$ during digestion.

\section{Reagents required}

- Mixed indicator: prepared by using $0.1 \%$ bromocresol green and $0.1 \%$ methyl red indicator in $95 \%$ alcohol.

- $4 \%$ boric acid

- $40 \%$ sodium hydroxide

- $1 \mathrm{~N} \mathrm{HCl}$

- Catalyst for digestion: digestion mixture (copper sulphate and potassium sulphate)

Digestion: weigh $250 \mathrm{mg}$ of sample and placed in $250 \mathrm{ml}$ Kjeldahl flask add 1 to $2 \mathrm{~g}$ of catalyst mixture and $7 \mathrm{ml}$ of conc. $\mathrm{H}_{2} \mathrm{SO}_{4}$ and placed in digestion chamber for an hour at $300^{\circ} \mathrm{C}$ and 2 hours at $400^{\circ} \mathrm{C}$ or until the colour of the digest was clear white.

Distillation: distillation of sample was carried out by automatic distillation unit, place the Kjeldahl flask in one chamber and conical flask in another chamber and press the button run. The distillation unit was first furnished with boric acid $(4 \%)$ and it was done for about $13 \mathrm{sec}$. and after that furnished with $\mathrm{NaOH}(40 \%)$ and it was done for about $9 \mathrm{~min}$, during this process the liberated ammonia gets trapped. During the distillation process the colour of the digests in the Kjeldahl flask was turned to pale blue.

Titration: the solution in the conical flask was titrated against the $1 \mathrm{~N} \mathrm{Hcl}$ by adding 1or 2 drops of mixed indicator till the brick red colour will come. The protein content of the sample was calculated by multiplying the nitrogen value by a factor 6.25 .

The result was calculated using the formula:

$$
\text { Protein }(\%)=\frac{14 * \text { Titre value } * \text { Normality of } \mathrm{Hcl}}{\text { Sample weight }(\mathrm{g})} * 6.25
$$


Fibre: The crude fibre of the sample was estimated by using moisture and fat free sample by Fibra plus apparatus. Transfer the $2-3 \mathrm{~g}$ of moisture and fat free sample to fibre estimating thimbers and placed in the digestion chamber. Add $150 \mathrm{ml}$ of boiling sulphuric acid solution to the chamber and set the temperature to $500^{\circ} \mathrm{C}$ for $10 \mathrm{~min}$ after that reduce the temperature to $400^{\circ} \mathrm{C}$ and leave it for $30 \mathrm{~min}$. after that drain out the acid by using suction pump and washed with boiled distilled water after acid wash the digestion chamber was filled with $150 \mathrm{ml}$ of boiling sodium hydroxide solution for about $30 \mathrm{~min}$ at $400^{\circ} \mathrm{C}$. Then drain out the alkali solution by using suction pump again the tubes were washed with boiled distilled water. After that place the crucibles in oven at $100^{\circ} \mathrm{C}$ for about one hour and take the weight of crucible after that place the crucible in muffle furnace at $550^{\circ} \mathrm{C}$ for 3 hours or until the white ash was formed and take the final weight.

The fibre content of sample was calculated by:

Crude fibre $\left(\frac{\mathrm{g}}{100 \mathrm{~g}}\right)=\frac{[100-(\text { moisture }+ \text { fat content of sample })] * \text { We }- \text { Wa }}{\text { weight of sample taken }}$

$\mathrm{W}_{\mathrm{e}}=$ Pre-weighed ash $(\mathrm{g})$

$\mathrm{W}_{\mathrm{a}}=$ Weight of dish after washing $(\mathrm{g})$

Growth and Yield parameters of mulberry

Plant height (cm): Plant height was recorded from the base of the main shoot to the top most fully opened leaf in five randomly selected plants under each treatment, in three replications. The mean of five plants was worked out to obtain the plant height.

\section{Number of branches per plant}

The number of branches in five randomly selected plants was counted in each treatment under each replication and the mean was worked out.

\section{Number of leaves per shoot}

The total number of leaves in each shoot of the plant was counted from five randomly selected mulberry plants.

\section{Leaf area $\left(\mathrm{dm}^{2}\right.$ plant $\left.^{-1}\right)$ :}

The area of third fully opened leaf from top was determined by multiplying length $\times$ breadth with a constant factor 0.6898 . The product was then multiplied with number of green leaves per plant to get leaf area per plant.

\section{Leaf yield ( g plant $\left.^{-1}\right)$}

Leaf yield per plant was recorded replication wise by harvesting fresh leaves from five randomly selected plants under each treatment and mean yield was calculated.

Table 1: Influence of Seri waste bio digester on biochemical constituents of V1 mulberry on $60^{\text {th }}$ day after pruning

\begin{tabular}{|c|c|c|c|c|}
\hline Treatments & $\begin{array}{c}\text { Moisture content } \\
(\%)\end{array}$ & $\begin{array}{c}\text { Total chlorophyll } \\
(\mathrm{mg} / \mathrm{g})\end{array}$ & Crude protein $(\%)$ & Crude fibre (\%) \\
\hline $\mathrm{T}_{1}$ & 70.32 & 2.21 & 18.36 & 1.22 \\
\hline $\mathrm{T}_{2}$ & 72.59 & 2.39 & 19.67 & 3.40 \\
\hline $\mathrm{T}_{3}$ & 73.10 & 2.40 & 20.09 & 4.65 \\
\hline $\mathrm{T}_{4}$ & 74.46 & 2.41 & 20.19 & 4.78 \\
\hline $\mathrm{T}_{5}$ & 73.82 & 2.44 & 19.69 & 3.78 \\
\hline $\mathrm{T}_{6}$ & 72.56 & 2.27 & 19.56 & 2.73 \\
\hline $\mathrm{T}_{7}$ & 72.19 & 2.25 & 19.52 & 2.26 \\
\hline $\mathrm{T}_{8}$ & 70.53 & 2.23 & 18.80 & 1.48 \\
\hline $\mathrm{T}_{9}$ & 71.49 & 2.22 & 19.30 & 1.76 \\
\hline $\mathrm{T}_{10}$ & 70.65 & 2.24 & 19.10 & 1.67 \\
\hline $\mathrm{T}_{11}$ & 71.55 & 2.25 & 19.51 & 2.13 \\
\hline F- test & $*$ & $*$ & $*$ & $*$ \\
\hline S.Em \pm & 0.113 & 0.005 & 0.116 & 0.022 \\
\hline C.D@ (5\%) & 0.332 & 0.014 & 0.342 & 0.064 \\
\hline
\end{tabular}

Moisture percentage of V1 leaves varied among different treatments. Mulberry raised with $\mathrm{T}_{4}(50 \%$ Seri Bio-digester effluent $+25 \%$ Biodigester effluent $+25 \% \mathrm{RDF}$ ) recorded highest leaf moisture $(74.46 \%)$ over other treatments followed by $\mathrm{T}_{5}(25 \%$ Seri Biodigester effluent $+25 \%$ Bio-digester effluent $+25 \%$ Vermicompost $+25 \%$ Compost) recorded as $73.83 \%$ of leaf moisture. Similarly, the lowest percentage of moisture $(70.32 \%)$ was recorded in $\mathrm{T}_{1}(100 \%$ Recommended dose of fertilizers). Increase in moisture content of leaves might be due to water retention capacity and slow and steady supply of moisture from seri biodigester liquid. Yokoyama (1974) ${ }^{[14]}$ reported that, usually moisture content of mulberry leaves varied from 64 to $83 \%$. Application of organic manures supplied all the nutrients to mulberry which inturn increased the moisture content (Ravikumar 2003) ${ }^{[9]}$.

Significant improvement was recorded in chlorophyll content of V1 leaves (Table 1). Maximum amount of total chlorophyll $(2.44 \mathrm{mg} / \mathrm{g})$ was encountered in $\mathrm{T}_{5}-(25 \%$ Seri Bio-digester effluent $+25 \%$ Bio-digester effluent $+25 \%$ Vermicompost +
$25 \%$ Compost $)$ followed by $\mathrm{T}_{4}(50 \%$ Seri Bio-digester effluent $+25 \%$ Bio-digester effluent $+25 \%$ RDF) which recorded, $2.41 \mathrm{mg} / \mathrm{g}$ of total chlorophyll. Similarly, the minimum chlorophyll was recorded in $\mathrm{T}_{1} \quad(100 \%$ Recommended dose of fertilizers) with $2.21 \mathrm{mg} / \mathrm{g}$ of total chlorophyll. Adequate supply of nutrients through seriwaste biodigester liquid may be attributable for increase in chlorophyll content in leaves. These observations are in agreement with findings of Shivakumar et al. (2000) [13] where, organic manures supplemented in different forms caused an increase of chlorophyll content of mulberry.

Varied amounts of crude protein and crude fibre contents were noticed in V1 mulberry among different treatments (Table 1). Maximum crude protein (20.19) and crude fibre (4.78) were recorded in $\mathrm{T}_{4}(50 \%$ Seri Bio-digester effluent + $25 \%$ Biodigester effluent $+25 \%$ RDF). The next best treatment was $\mathrm{T}_{3}(50 \%$ Seri Bio-digester effluent $+25 \%$ Compost $+25 \%$ RDF) which showed $20.09 \%$ of crude protein and 4.65 of crude fibre $\%$ followed by $\mathrm{T}_{5}$ (25\% Seri 
Bio- digester effluent $+25 \%$ Bio-digester effluent $+25 \%$ Vermicompost $+25 \%$ Compost) that recorded $19.69 \%$ of crude protein and 3.78 of crude fibre percentage. Increase in crude protein and crude fibre might be due to the availability of nitrogen in the plants. Similar kinds of results were observed in studies of Ray et al. (1973) ${ }^{[10]}$ who reported that, application of organic and inorganic nutrients resulted in increase in crude protein and crude fibre contents of mulberry. Shankar et al. (2002) ${ }^{[12]}$ revealed that, slow release of nutrients from organic matter mulberry supplied garden might result in higher crude protein and crude fibre in leaf.

Table 2: Influence of Seri waste bio digester on growth and yield parameters in V1 mulberry at $60^{\text {th }}$ days after pruning.

\begin{tabular}{|c|c|c|c|c|c|}
\hline Treatments & Plant height $(\mathrm{cm})$ & Number of Branches/plant & Number of Leaves/Branch & Leaf area $\left(\mathrm{dm}^{2}\right)$ & Leaf yield (g/plant) \\
\hline $\mathrm{T}_{1}$ & 147.05 & 9.92 & 23.67 & 184.50 & 897.33 \\
\hline $\mathrm{T}_{2}$ & 158.45 & 12.50 & 26.81 & 200.00 & 998.33 \\
\hline $\mathrm{T}_{3}$ & 161.37 & 12.65 & 29.15 & 208.00 & 1010.33 \\
\hline $\mathrm{T}_{4}$ & 163.19 & 13.32 & 33.00 & 208.33 & 1012.33 \\
\hline $\mathrm{T}_{5}$ & 160.05 & 12.52 & 28.17 & 204.00 & 999.00 \\
\hline $\mathrm{T}_{6}$ & 154.31 & 12.5 & 26.37 & 191.28 & 949.00 \\
\hline $\mathrm{T}_{7}$ & 153.99 & 10.88 & 26.18 & 190.18 & 940.00 \\
\hline $\mathrm{T}_{8}$ & 149.09 & 10.03 & 24.74 & 184.67 & 909.00 \\
\hline $\mathrm{T}_{9}$ & 152.41 & 10.24 & 25.59 & 185.67 & 916.00 \\
\hline$T_{10}$ & 151.19 & 10.24 & 25.08 & 184.83 & 916.00 \\
\hline $\mathrm{T}_{11}$ & 153.83 & 10.69 & 26.09 & 185.00 & 926.00 \\
\hline F- test & $*$ & $*$ & $*$ & $*$ & $*$ \\
\hline S.Emt & 0.487 & 0.054 & 1.663 & 0.982 & 4.762 \\
\hline C.D@ (5\%) & 1.436 & 0.159 & 4.907 & 2.897 & 14.048 \\
\hline
\end{tabular}

The maximum plant height $(163.19 \mathrm{~cm})$, number of branches per plant (13.32) and more number of leaves per plant (33.00) at $60^{\text {th }}$ day after pruning recorded significantly higher values in mulberry raised with $(50 \%$ Seri Bio-digester effluent $+25 \%$ Biodigester effluent $+25 \%$ RDF. The next best treatment was application of $\mathrm{T}_{3} \quad(50 \%$ Seri Bio-digester effluent $+25 \%$ Compost $+25 \%$ RDF) where in plant height recorded was $161.37 \mathrm{~cm}$, number of branches per plant recorded was 12.65 and number of leaves per plant was 29.15. However, lowest traits were recorded when mulberry was raised with $\mathrm{T}_{1}$ (100\%Recommended dose of fertilizers) with $147.05 \mathrm{~cm}$ of plant height, 9.92 of number of branches per plant and 23.67 leaves per plant. Plant height profoundly increased due to nitrogen addition to the soil through seri waste biodigester liquid along with recommended dose of fertilizers and biodigester liquid. More the plant height, more was the number of branches and leaves. Similar results were observed by Shivakumar et al. (2000) ${ }^{[13]}$ as per whom the combination of organic manures and inorganic fertilizers helped to increase the plant height and number of branches and leaves.

Significant variation was noticed with regard to leaf area and leaf yield per plant of V1 mulberry among the different treatments (Table 2). Among the different treatments, leaf area $\left(208.33 \mathrm{dM}^{2}\right)$ and leaf yield (1012.33 g/plant)were significantly higher in $\mathrm{T}_{4}(50 \%$ Seri Bio-digester effluent + $25 \%$ Biodigester effluent $+25 \% \mathrm{RDF})$ followed by $\mathrm{T}_{3}(50 \%$ Seri Bio-digester effluent $+25 \%$ Compost $+25 \%$ RDF) recorded leaf area of $208.00 \mathrm{dM}^{2}$ and leaf yield of 1010.33 $\mathrm{g} /$ plant and $\mathrm{T}_{5}(25 \%$ Seri Bio-digester effluent $+25 \%$ Biodigester effluent $+25 \%$ Vermicompost $+25 \%$ Compost) recorded leaf area of $\left(204 \mathrm{dM}^{2}\right)$ and leaf yield of plant $(909$ $\mathrm{g} / \mathrm{plant}$ ). The lowest values of leaf area (184.50) and leaf yield
(897.33) were recorded in $T_{1}(100 \%$ Recommended dose of fertilizers). The leaf area and leaf yield per plant increased due to positive influence of seriwaste bio digester liquid. The combination of Seri waste bio digester liquid along with biodigester liquid and recommended dose of fertilizers might have helped in slow release of macro and micro-nutrients. The lowest leaf area and leaf yield in $\mathrm{T}_{1}(100 \%$ Recommended dose of fertilizers) may be due to shorter plant height and lowest number of leaves and may be due to insufficiency of nutrients to the root zone. The present findings are comparable to the results of Narayanaswamy et al. (2006) ${ }^{[7]}$ who reported that, application of organic manures with combination of organic manures and inorganic fertilizers recorded higher yield compared to NPK alone in $S_{36}$ mulberry.

Macro nutrients have significantly increased with the application of seriwaste biodigester liquid in V1 leaves (Table 3 ). The significantly higher leaf nitrogen, phosphorus and potassium contents of $3.33 \%, 1.80 \%$ and $1.63 \%$ was noticed in $\mathrm{T} 4(50 \%$ Seri Bio-digester effluent $+25 \%$ Biodigester effluent $+25 \% \mathrm{RDF})$ followed by $\mathrm{T}_{5}(25 \%$ Seri Bio-digester effluent $+25 \%$ Bio-digester effluent $+25 \%$ Vermicompost + $25 \%$ Compost) which recorded $3.29 \% \mathrm{~N}, 1.74 \% \mathrm{P}$ and $1.61 \% \mathrm{~K}$ and T3 $(50 \%$ Seri Bio-digester effluent $+25 \%$ Compost + $25 \% \mathrm{RDF}$ ) that resulted in $3.26,1.70$ and $1.61 \%$ of NPK, respectively. Increase of macronutrients of leaf may be mainly due to the application of seriwaste biodigester liquid which is the rich source of NPK. Murali et al. (2006) ${ }^{[6]}$ reported that uptake of NPK was increased by integration of organic manures and inorganic fertilizers in S36 and M5 mulberry.

Table 3: Influence of Seri waste bio digester on macronutrient and secondary nutrient contents of V1 mulberry leaves on $60^{\text {th }}$ day after pruning

\begin{tabular}{|c|c|c|c|c|c|c|}
\hline Treatments & Nitrogen (\%) & Phosphorus (\%) & Potassium (\%) & Calcium (\%) & Magnesium (\%) & Sulphur (\%) \\
\hline $\mathrm{T}_{1}$ & 3.14 & 0.90 & 1.11 & 0.78 & 0.55 & 0.26 \\
\hline $\mathrm{T}_{2}$ & 3.26 & 1.68 & 1.57 & 1.12 & 0.69 & 0.31 \\
\hline $\mathrm{T}_{3}$ & 3.26 & 1.70 & 1.61 & 1.13 & 0.71 & 0.35 \\
\hline $\mathrm{T}_{4}$ & 3.33 & 1.80 & 1.63 & 1.19 & 0.73 & 0.73 \\
\hline $\mathrm{T}_{5}$ & 3.29 & 1.74 & 1.61 & 1.14 & 0.72 & 0.69 \\
\hline $\mathrm{T}_{6}$ & 3.23 & 1.63 & 1.52 & 1.08 & 0.69 & 0.30 \\
\hline $\mathrm{T}_{7}$ & 3.23 & 1.57 & 1.51 & 0.95 & 0.64 & 0.30 \\
\hline $\mathrm{T}_{8}$ & 3.19 & 1.20 & 1.15 & 0.78 & 0.57 & 0.28 \\
\hline $\mathrm{T}_{9}$ & 3.21 & 1.53 & 1.41 & 0.91 & 0.60 & 0.59 \\
\hline $\mathrm{T}_{10}$ & 3.21 & 1.51 & 1.39 & 0.84 & & 0.28 \\
\hline
\end{tabular}




\begin{tabular}{|c|c|c|c|c|c|}
\hline $\mathrm{T}_{11}$ & 3.22 & 1.53 & 1.47 & 0.93 & 0.29 \\
\hline F- test & $*$ & $*$ & $*$ & $*$ & $*$ \\
\hline S.Em \pm & 0.010 & 0.038 & 0.011 & 0.011 & 0.007 \\
\hline C.D@ (5\%) & 0.030 & 0.112 & 0.031 & 0.034 & 0.006 \\
\hline
\end{tabular}

Table 4: Influence of Seri waste bio digester on micronutrient contents of V1 mulberry leaves on $60^{\text {th }}$ day after pruning

\begin{tabular}{|c|c|c|c|c|}
\hline Treatments & $\begin{array}{c}\text { Iron } \\
(\mathbf{p p m})\end{array}$ & Manganese (ppm) & Copper (ppm) & $\begin{array}{c}\text { Zinc } \\
(\mathbf{p p m})\end{array}$ \\
\hline $\mathrm{T}_{1}$ & 245.54 & 50.50 & 29.69 & 37.64 \\
\hline $\mathrm{T}_{2}$ & 286.53 & 52.24 & 31.93 & 40.94 \\
\hline $\mathrm{T}_{3}$ & 289.47 & 54.18 & 32.74 & 42.81 \\
\hline $\mathrm{T}_{4}$ & 288.52 & 53.33 & 32.39 & 41.41 \\
\hline $\mathrm{T}_{5}$ & 301.79 & 54.28 & 33.10 & 43.02 \\
\hline $\mathrm{T}_{6}$ & 278.35 & 51.82 & 31.79 & 40.58 \\
\hline $\mathrm{T}_{7}$ & 245.98 & 51.36 & 31.74 & 40.52 \\
\hline $\mathrm{T}_{8}$ & 194.53 & 49.50 & 28.65 & 37.57 \\
\hline $\mathrm{T}_{9}$ & 233.50 & 50.64 & 30.63 & 38.87 \\
\hline $\mathrm{T}_{10}$ & 176.32 & 41.43 & 28.60 & 36.84 \\
\hline $\mathrm{T}_{11}$ & 245.54 & 51.34 & 31.70 & 39.67 \\
\hline $\mathrm{F}-\mathrm{test}$ & $*$ & $*$ & $*$ & $*$ \\
\hline $\mathrm{S} . \mathrm{Em} \pm$ & 0.986 & 0.342 & 0.573 & 0.574 \\
\hline C.D@ $(5 \%)$ & 2.909 & 1.010 & 1.692 & 1.695 \\
\hline
\end{tabular}

Secondary nutrients viz., calcium, magnesium and sulphur and micronutrients such as iron, manganese, copper and zinc of V1 mulberry leaves were highly influenced by application seri waste biodigester liquid (Table 3, 4). Among all the treatments, mulberry raised with $\mathrm{T} 4(50 \%$ Seri Bio-digester effluent $+25 \%$ Biodigester effluent $+25 \% \mathrm{RDF}$ ) recorded higher calcium content $(1.19 \%)$, magnesium content $(0.73 \%)$ and sulphur content $(0.73 \%)$ followed by $\mathrm{T}_{5}(25 \%$ Seri Biodigester effluent $+25 \%$ Bio-digester effluent $+25 \%$ Vermicompost $+25 \%$ Compost) which registered $1.14 \% \mathrm{Ca}$, $0.72 \% \mathrm{Mg}$ and $0.69 \% \mathrm{~S}$. Among all the treatments, the micronutrients were significantly higher in $\mathrm{T}_{5}(25 \%$ Seri Biodigester effluent $+25 \%$ Bio-digester effluent $+25 \%$ Vermicompost $+25 \%$ Compost) with $301.79 \mathrm{ppm}$ iron, 54.28ppm manganese, 33.10ppm copper and 43.02ppm zinc followed by T4 (50\% Seri Bio-digester effluent $+25 \%$ Biodigester effluent $+25 \%$ RDF) that recorded 288.52, 53.33, 32.39 and $41.41 \mathrm{ppm}$ of iron, manganese, copper and zinc, respectively. The increase in secondary and micro nutrients might be due to application of seriwaste biodigester liquid at different levels to supply the recommended dose of nutrients for quality leaves and productivity. Murali et at. $(2006)^{[6]}$ too observed that the combination of organic manures with inorganic fertilizers have yielded significantly higher calcium, magnesium and sulphur contents in S36 and M5 leaves of mulberry.

\section{References}

1. AOAC. Official Methods of Analysis. (Ed. Daniel Banes), A.O.A.C., Washington D.C., Bangalore, 1980, 105.

2. Arnon, Bajpai RK, Shrikant Chitale, Upadhyay SK, Urkurkar JS. Long term studies on soil physical-chemical properties and productivity of rice-wheat system as influenced by integrated nutrient management in Inceptisol of Chhattisgarh. J Indian Soc. Soil Sci. 1949; 54(1):24-29.

3. Hiscox JD, Israelstam GF.A method for estimation of chlorophyll from leaf tissue without maceration. Can. J Bot. 1979; 57:1332-1334.

4. Jackson ML. Soil chemical analysis, Prentice Hall of India (Pvt.) Ltd., New Delhi, 1967, 498.
5. Lindsey WL, Norwell WA. Development of DTPA soil test for zinc, iron, manganese and copper. Soil Sci. Soc. Am. J. 1978; 42:421-428.

6. Murali C, Sreeramulu KR, Narayanaswamy TK, Shankar MA, Amarnath N. Effect of bioinoculants and organic manures on the yield and quality of S36 mulberry. Natl. Sem. Soil Health and Water Management for Sustainable Sericulture. $27^{\text {th }}$ and $28^{\text {th }}$ September, Regional Sericultural Research Station (A unit of CSB), Bangalore-India, 2006, 90.

7. Narayanaswamy TK, Rajegowda Shankar MA, Sreeramulu KR. Effect of different organic manures on growth and yield parameters of M5 and S36 mulberry varieties in relation to silkworm growth. Research on Crops. 2006; 7(2):541-543.

8. Preston TR, Leng RA. The greenhouse effect and its implications for world agriculture. The need for environmentally friendly development. Livestock Research for Rural Development. 1989; 1(1):21-30.

9. Ravikumar A. Performance of mulberry and silkworm hybrids as influenced by different sources of nitrogen to mulberry. Ph.D. (Seri.) Thesis, UAS, Bangalore, 2003, 186.

10. Ray D, Mandal LN, Pain AK, Mandal SK. Effect of NPK and farm yard manure on the yield and nutritive value of mulberry leaf. Indian J Seric. 1973; 12:7-12.

11. Rodriguez L, Preston TR. Recent developments in the recycling of livestock excreta; an essential feature of sustainable farming systems in the tropics, 1996.

12. Shankar MA, Nagaraju Rangaswamy BT, Anitha Peter, Joseph Wiebel. Response of silkworm (Bombyx mori L.) to mulberry varieties, spacing and potassium sources under rainfed condition. Crop Res. 2002; 24:53-57.

13. Shivakumar HR, Nageshchandra BK, Nagarajaiah C, Jagadish KS. Impact of combined use of organic manures and inorganic fertilizers on growth, leaf yield and quality of mulberry. In: Moriculture in tropics (Eds. K.P. Chinnaswamy, R. Govindan, N.K. Krishnaprasad and D.N.R. Reddy) Proc. Natl. Sem. Tropic. Seric., Univ. Agri. Sci., Bengaluru, Karnataka, India. 2000; 1:94-96.

14. Yokoyama T. Sericulture. Ann. Rev. Entomol. 1974; 18:287-288. 